\title{
Shakespeare's Treasure Trove of Italian Tales
}

\author{
Pavel Drábek
}

Melissa Emerson Walter. The Italian Novella and Shakespeare's Comic Heroines. Toronto: University of Toronto Press, 2019. 279 pp. ISBN 978-1-4875-0364-2.

This article was supported by the Czech Science Foundation project GA19-07494S. English Theatre Culture 1660-1737.

It is quite the rarity that a new book redefines the Shakespearean terrain in a substantial way. Most of the fundamental insights into the cultural knowledge, traditions and practices that constituted Shakespeare's worldview are in many ways a matter of older criticism - from E. M. W. Tillyard's influential (though dated) study The Elizabethan World Picture (1943), through Muriel C. Bradbrook's The Growth and Structure of Elizabethan Comedy (1955), Geoffrey Bullough's monumental 8-volume Narrative and Dramatic Sources of Shakespeare (1957-1975), Leo Salingar's Shakespeare and the Traditions of Comedy (1973); to the more recent work of Jonathan Bate (Shakespeare and Ovid, 1993) or Robert Miola (Shakespeare and Classical Tragedy: The Influence of Seneca, 1992; and, Shakespeare and Classical Comedy: The Influence of Plautus and Terence, 1994). Recently, only a very limited number of scholars have revisited and re-posited Shakespeare as a dramatist "in his world" - especially the indefatigable Stanley Wells, Andrew Gurr, Peter Thompson, and the groundbreaking researchers of theatre practice Tiffany Stern, Farah Karim-Cooper or Lucy Munro, to name a few.

I am convinced that Melissa Walter's monograph The Italian Novella and Shakespeare's Comic Heroines is one such fundamental contribution to a field that is only very recently coming back as a centre of critical attention: source studies - crucially also revisited in Melissa Walter and Dennis Britton's collection Rethinking Shakespeare Source Study (Routledge, 2018). In 2015, Charlotte Artese published an important study on Shakespeare's Folktale Sources (University of Delaware Press, 2015), followed by her edited volume of Shakespeare and the Folktale: An Anthology of Stories (Princeton University Press, 2019). These are source studies of a modern kind: no longer in tow of the late nineteenth-century and early to mid-twentieth-century obsession with genealogy and the play's "family trees", these modern studies are closer to adaptation theory and to the imaginative dramaturgies of Shakespeare's plays that recast their inspirations into new shapes and existences. In the case of Walter's study, the crucially new ground broken is her transnational purview: Shakespeare is no longer just an English national poet and dramatist who loots the world's treasure for his benefit - a colonial politics of appropriation that is both inappropriate on many levels and historically wrong. Melissa Walter's book is impressively good on the transnational context with Shakespeare as a cosmopolitan European rooted within a multilingual and multicultural environment in London:

The demand for French and Italian books in London was met by imports (the semi- 
-annual Frankfurt book fair being one prominent continent site of circulation) and also by local printers. John Wolfe, who printed in the Italian language in London from 1579 to 1591, printed language learning manuals, Protestant works, and other books banned in Italy such as works by Machiavelli and Aretino. With the editorial collaboration of Giacopo Castelvetro, Wolfe also printed Tasso's Aminta and Guarini's Il Pastor Fido in London (in Italian) in 1591. The Stationer's Register lists a Decameron licensed to Wolfe on 13 September 1587 , but no copies have been found. The first extant translation of the full Decameron into English (attributed to John Florio and dedicated to Sir Philip Herbert, Knight of the Bath) was printed in 1620 by Isaac Jaggard. (22)

To this mind-whirling account should be added two endnotes that are about three times the length of this passage. The fact that these endnotes to a paragraph on page 22 are number 105 and 106, is another important aspect of Walter's book. What Walter writes in the main text - an introduction and five chapters, covering 145 pages - is supported by endnotes covering 68 pages in petit and two appendices (15 pages) with lists of Italian and French novellas in England and the plays they inspired. In fact, The Italian Novella are two books in one - or if you wish, a tip of an iceberg submerged in the endnotes, or six chapter gems picked from a treasure trove of knowledge comprising book history, dramatic literature, literary studies, comparative literature, theatre theory, and gender studies. Walter is unnecessarily modest about her achievement: her study is firmly rooted in rigorous literary, historical as well as theoretical research
- her deployment of theatre semiotics, proxemics and structuralist aesthetics is one of the most competent applications I have encountered - and the implications of this rigorous treasure of knowledge are far-reaching.

What is Shakespeare after Walter's book? Not only an avid, omnivorous reader of Italian tales (this much has long been known, not least thanks to Jason Lawrence's 2005 book on Italian language learning and literary imitation in early modern England), just like he was obsessed with Ovid (as shown by Bate) but also a comediograph whose dramatic dialogues and situations embody the social space of the Italianate novella. Referring to Shakespeare's early comedies The Two Gentlemen of Verona, The Taming of the Shrew and Much Ado About Nothing and specifically focusing on female characters and heroines as central to and empowered in these dialogues and situations, Walter articulates what those imagined spaces meant in the playhouse:

When Shakespeare's audience saw these early Italianate comedies, they had the opportunity to participate vicariously in elite civility, to discuss the issues raised, and to extend this space of conversation into an incipient public sphere. [...] Shakespeare may have found appealing the model [...] that emphasizes the agency of the speaker to retell known stories in new contexts, with new twists, and to tell stories in response to social concerns or questions. (43)

This is a crucial point and speaks to our modern notion of (what might be called) "affective aesthetics" - that centres epistemologically on the immediate sensation (emotional, intellectual and social) of the here and now of performance. 
Affective aesthetics is a modern development of phenomenology, one could say, and should be kept distinct from presentism and its somewhat historically myopic and navelgazing concern for our current predicament. ${ }^{1}$ Affective aesthetics could probably best be expressed in the words of Susanne Wofford: "foreign emotions" - that is, the profoundly human capacity to experience mental states that are vicarious, external to us, propositional. Theatre, performance as well as literature, is central to facilitating these cathectic possible worlds that allow us to learn and experience what exceeds us. Wofford is Walter's great inspiration - a "brilliant mentor" (as her Acknowledgements put it) - and the kudos for the transnational purview, the ethics of close reading and a serious engagement with the Italian culture when it comes to Shakespeare goes to her. (In this context, the Theater Without Borders research collective needs mentioning, of which Wofford, Walter as well as myself are members, along with several authorities in Walter's bibliography.)

Shakespeare at Walter's hands is a citizen of the cultural Europe: The Merry Wives of Windsor may be set in the heart of little England, but the tropes, tricks, tales, talk and figures are all transnational. This is much more the world of Boccaccio's Florence than of a Tudor town (see Chapter 4). The same can be said of another dozen plays of Shakespeare: comedies, tragicomedies and tragedies (Romeo and Juliet, Othello). Following Walter's impulse through and applying it to the rest of the Shakespearean canon and beyond will have a lasting impact. Is Shakespeare's Italianate dramaturgy the

1 For a recent critical account of presentism, see (RAMALHETE GOMES 2021). "old style" that made him publish sonnets decades after their heyday? Was it keeping alive the memory of the $1570 \mathrm{~s}$ and $1580 \mathrm{~s}-$ the clowneries of Richard Tarlton (and his Boccaccian associations) and his follower Will Kemp, who was also the main clown in Shakespeare's Italianate comedies? It seems plausible that Shakespeare's dramaturgy hearkened back to Stephen Gosson's jibe of 1582:

I have seen it that the Palace of Pleasure [William Painter's collection of Italianate novellas], the Golden Ass, the Ethiopian History, Amadis of France, the Round Table, bawdy comedies in Latin, French, Italian and Spanish have been thoroughly ransacked to furnish the playhouses in London. (Plays Confuted in Five Actions, London 1582, D6v; quoted in Walter, page 180 , note 74 )

In this context, the Shakespearean apocrypha and "suspect" plays - such as the megahit Mucedorus (first printed 1598, but dating back to the 1580s probably), Edward III (with a subplot taken from an Italian novella in Painter) or the Shakespeare-Fletcher collaboration The Two Noble Kinsmen (taken from Chaucer's Boccaccian The Canterbury Tales) - should also be reconsidered, just like the plays that crucially derive from a contamination of Shakespeare and the Italianate novella tradition - such as John Fletcher's Women Pleased (16191623), based on Chaucer's "The Wife of Bath's Tale", or James Shirley's The Bird in a Cage (1633) and its afterlives in Aphra Behn's The Lucky Chance (1686) ${ }^{2}$ as well as in the plays of the English travelling actors in German-speaking Europe.

2 For the relationship between Shirley's The Bird in a Cage and Behn's The Lucky Chance, see Teresa Grant's essay in this issue. 
Apart from the Italian novella and Shakespeare's comic heroines, Walter's book has another protagonist: an enclosed space. Truly a hero that comes in a thousand variants, as enclosed chambers, closets, trunks, caskets, but also spacies of social or semantic closure; this is an overarching feature that plays a crucial part in the plots, the situations as well as Walter's agenda of female emancipation and autonomy - regularly yoked in a patriarchal system of treating women as possessions to be locked up. Or, as Portia puts it in The Merchant of Venice (discussed incisively in Chapter 2):

I may neither choose who I would nor refuse who I dislike; so is the will of a living daughter curbed by the will of a dead father. (The Merchant of Venice, 1.2.22-24; discussed by Walter on p. 52ff.)

Among the implications of Walter's study of caskets and trunks is another history, truly transnational, linked to Shakespeare's original Falstaff, Will Kemp. Kemp's signature piece, known as Kemp's Jig or The Singing Simpkin (as Lucie Skeaping and Roger Clegg recently studied; briefly cited by Walter), had a transnational reach. Known and printed in German as Pickelhering in der Kiste (1620; Pickelhering in a Trunk), and later in Dutch and Swedish, the trunk became not only a supreme comedic property, but also a treasure trove that carried the heritage of the Italian novella throughout languages, countries, cultures and centuries.

Once delving into Melissa Walter's treasury of Italianate tales, other paths open: Shakespeare's and Wilkins's Pericles (mentioned on p. 144) brings to life John Gower as the narrator and his story of Apollonius of Tyre from Confessio Amantis, a verse col- lection contemporary with The Canterbury Tales and deriving from a related transnational culture of Romance tales that combined Italian novellas and the classical Greek novel. The Winter's Tale becomes also Italianate, mediated through Shakespeare's source, Robert Greene's superpopular novella Pandosto or The Triumph of Time, which belongs with Greene's other novellas to the courtly culture of the Italian Renaissance. And The Tempest, while it has no direct acknowledged source, is clearly associated with the Italian commedia dell'arte and its own transformations of the courtly novella. Under Walter's critical touch, Shakespearean dramaturgy opens up to reveal a rich and imaginative world of tales that form a solid bedrock for a great number of plays by Shakespeare and some of his contemporaries the transnationally minded ones, that is.

Melissa Walter's The Italian Novella and Shakespeare's Comic Heroines is a carefully thought-out, incisive and consequential study that will ruffle received understanding of Shakespeare's dramaturgy - just like it challenges the comfortable cognitive closure within his comedies.

Shakespeare's early Italianate comedies demonstrate a sense of the theatre as a place for negotiating standards of civility, and the witty female characters in these plays make moves that are similar to female characters in the frame tales of novella collections. [...] As a reader, Shakespeare was choosing his own interpretations and responses to these stories, and the retellings in his interpretations and responses to these stories, and the retellings in his plays, developed in the collaborative creative context of early modern playmaking and performance, reflect these choices. The retellings needed to appeal 
to Shakespeare's cross-gender, cross-class audiences to be successful. Commodification, female agency, and contested views of gender and the family were among these audience members' concerns. The early modern theatre, a place of debate and imaginative liberation, allowed exploration of issues of autonomy, authority, and embodiment via novellesque materials. It engaged the audience in these problems and invited audience members to consider their own implication in the staged events. However contested, illusory, unequal, or impermanent the effects may have been, Shakespeare's comedies explore the stage as a place of potential liberation and widening civil conversation. $(27,26)$

It also needs to be added that this imaginary and imaginative space of enfranchise- ment and social liberation is specifically female - in keeping with the long tradition from Boccaccio, through Giambattista Basile, Matteo Bandello, Margaret of Navarre, Geoffrey Chaucer, William Painter down to the fisherwomen of Westward for Smelts (1603/1620). It centres on the art of free conversation and inspirational storytelling. For recognising this so fully and placing it literally centre stage, the thanks go to Melissa Walter.

\section{Bibliography}

RAMALHETE GOMES, Miguel. 2021. Presentist studies. In Evelyn Gajowski (ed.). The Arden Research Handbook of Contemporary Shakespeare Criticism. London: Bloomsbury, 2021: 233-246. 